\title{
Олександр РЕЄНТ
}

доктор історичних наук, професор, член-кореспондент НАН України, заступник директора Інституту історії України НАН України (Київ, Україна), Reent.O.P@nas.gov.ua

ORCID: https://orcid.org/oooo-oooI-5I4I-7445

\section{Олександр СЕРДЮК}

кандидат історичних наук

(Київ, Україна), historydepartmentı9@gmail.com

ORCID: https://orcid.org/oooo-ooo2-2I09-7900

\section{Чорносотенці: український аспект (кінець XIX - 1917 р.)}

\author{
DOI: https://doi.org/10.15407/uhj2021.05.091 \\ УДК: 94(100+329-477)XX
}

\begin{abstract}
Анотація. Мета статті - реконструювати та проаналізувати основні етапи й особливості чорносотенного руху в Україні наприкінці XIX ст. та у часи Першої світової війни. Методологія грунтується на принципах історизму, об'єктивності. Використано порівняльно-історичний, аналітично-септичний методи, методики наукової критики джерел, міждисциплінарний підхід. Наукова новизна. На підставі опрацьованих джерел, значна частина яких уперше вводиться в науковий обіг, охарактеризовано специфіку чорносотенного руху в Україні у вказаний час. Результати дослідження. Проблематика чорносотенного руху в Російській імперії на початку XX ст., попри всю її складність і суперечливість, досить успішно досліджується російськими, українськими, єврейськими та іншими істориками й публіцистами вже понад століття. Істотно вивчена історія виникнення і становлення чорносотенних партій та організацій, їх чисельність, соціальний склад в Україні і загалом в імперії. Проаналізовано різні течії у чорносотенстві - від поміркованих до екстремістських, хід єврейських погромів та причини антисемітизму. Менше уваги дослідники приділили зв'язкам чорносотенців, їхніх очільників із російським монархізмом, широкою селянською масою та ієрархами православної церкви. Ще слабше висвітлено думську тактику чорносотенців, їх ставлення до маніфесту від 17 жовтня 1905 р., проблеми конституціоналізму після обнародування останнього. Серйозною прогалиною у вітчизняній історіографії залишається діяльність чорносотенців у роки Першої світової війни.
\end{abstract}

Ключові слова: чорносотенний рух, Російська імперія, Україна, єврейські погроми, урядова національна політика.

Різні аспекти заявленої теми слід досліджувати на широкому тлі життя тодішньої Російської імперії, що запізнилася на шляху політико-правового та соціальноекономічного розвитку. До того ж держава була надзвичайно багатонаціональною. Етнічні росіяни становили лише 43\% від усього населення. Зародився й почав набирати сил національно-визвольний рух, а водночас спостерігався ріст російського націоналізму, про що свідчила, наприклад, полеміка у часопису «Слово», заяви його учасників щодо необхідності «будівельного, державного 
націоналізму» , визначення того, що «культурні сили великоросійської народності [...] виявилася занадто слабкими» для російщення всього населення країни ${ }^{2}$. Водночас пропагувалася теза, що імперія була створена не тільки «однією фізичною силою, але й моральною»³. За оцінкою тогочасних учасників полеміки, у цих та інших висловлюваннях проявилися «душевні почуття російської інтелігенції», а з іншого боку, - лукавство, змішане з надією на прискорене російщення націй і народностей.

Іншою була практика російської влади, особливо представників «консервативної бюрократії», у національному питанні. Вона спрямовувалася перш за все на те, щоб зменшити питому вагу інших націй шляхом асиміляції або еміграції. I це особливо не приховувалося. Так, міністр внутрішніх справ Росії В.Плеве в розмові із засновником сіоністського руху австрійським лібералом Т.Герцлем, котра відбулася у Санкт-Петербурзі 1903 р., пояснював, що єврейське питання для Росії не життєве, утім важливе, тож «ми прагнемо вирішити його правильним шляхом [...] Ми хочемо асимілювати євреїв, але асиміляція [...] йде дуже повільно. Тому уряд доброзичливо ставиться до еміграції сіоністів у Палестину й готовий підтримати іiі перед Оттоманською імперією. Інтелігентні та заможні елементи, що можуть асимілюватися, ми охоче залишимо у себе, а бідних і малокультурних ми б залюбки позбулися» ${ }^{4}$. Таке тлумачення російсько-єврейських взаємовідносин цілковито схвалював імператор Микола II's.

На початку XX ст. взаємовідносини єврейського населення з владою стали напруженішими. Революційно налаштована єврейська молодь брала активну участь в антиурядових заходах, мотивуючи це різними утисками, обмеженнями громадянських прав. У відповідь у країні нагнітався антисемітизм. Юдофобський постулат пропагувався чорносотенцями, і взагалі часописами правого спрямування - «Московскими ведомостями», «Земщиною», «Новым временем», а в Україні - «Киевлянином». Для прикладу, зі сторінок «Земщины» буквально лилася ненависть до євреїв. Водночас часопис славословив імператора та його покровительство над чорносотенним Союзом російського народу. О.Солженіцин, що досліджував історію російсько-єврейських взаємин, писав, що вони «клином входили в події, в людську психологію і викликали палкі пристрасті», висвітлювати їх - «наче йти по лезу ножа» ${ }^{6}$. Заради справедливості слід відзначити, що суперечності того часу не меншою мірою загострили відносини російської держави з поляками, українцями та багатьма іншими народами, що входили до складу імперії.

Чорносотенство представляло собою доволі широкий спектр політичних партій та організацій, створених для захисту монархії й боротьби з революційним рухом. Найбільш масовим і дієвим серед них став Союз російського народу $(\mathrm{CPH})$, заснований у розпалі революції г905-1907 рр. Щодо України, то тут діяли І45і осередок (г97 686 членів). Зокрема у Волинській губернії - IIзI організація (99 336 членів), у Київській - 54 (го 976), Подільській - 71 (14 673), Катеринославській - I4 (I7 386), Полтавській - 67 (8564), Харківській - 8 (9273),

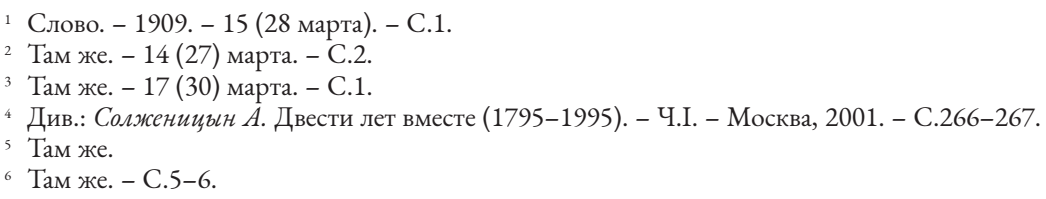


Херсонській - 24 (I7 I04), Чернігівській - 4I (8І22). Ще ІІ осередків СРН (3І52 члени) функціонували в Акерманському й Хотинському повітах Бессарабської губернії. Наведені цифри свідчать, що на Правобережжі України (Волинь, Київщина, Поділля) було І256 чорносотенних організацій, в яких налічувалося 124985 членів, що становило 63,22\% від усієї кількості в губерніях Наддніпрянщини. На одній тільки Волині налічувалося 99336 членів СРН, або 50,25\% від загальноукраїнського показника. Це були переважно дрібні організації, відділи та підвідділи в містечках і селах України.

Позиції войовничого націоналізму всіляко підтримував Клуб російський націоналістів у Києві. Найбільш визначними фігурами в ньому були член Державної думи А.Савенко, член Державної ради Д.Піхно. Зокрема перший наполегливо поширював тезу, що «України немає, є Малоросія як частина неподільної Росії». За оцінкою члена Держдуми від Києва Іванова, це був «оратор відомого, визначеного урядом зразка» ${ }^{8}$ Робив також заяви щодо української мови, якої начебто «немає», або iï «створили в Австрії», «придумав професор М.Грушевський», а українці її «не розуміють».

Феноменальними виявилися успіхи чорносотенців на виборах до III Державної думи в Україні, особливо у правобережних губерніях. Уряд послідовно підтримував чорносотенські організації матеріально й поліцейською силою до тих пір, поки не була розпущена II Дума. Проте після зміни виборчого закону ситуація змінилася. У III Думі вже переважали бажані для влади представники правих та ультраправих сил. Уряд, безперечно, ураховував цю обставину й певною мірою відійшов від прямого протегування, зменшив обсяги субсидування чорносотенців під впливом ряду чинників, зокрема потребуючи позик від західних кредиторів. Тому ультраправі зосередили свої зусилля на ігноруванні Жовтневого маніфесту та його правових наслідків.

Ультраправі піддівали різкій критиці вищих урядовців, своїх опонентів і голову Думи за нібито «недостатньо тверду» політику, навіть за натяки, що «їм не чужі конституційні принципи». Суть промов і заяв ультраправих із думської трибуни найчастіше зводилася до «гри на публіку». Виступи чорносотенців спрямовувалися на розпалювання інстинктів натовпу, в їх основі лежали антисемітизм і ксенофобія.

Праві й ультраправі продовжували стояти на захисті великого землеволодіння. Важливу роль у чорносотенному русі в Україні було відведено Свято-Успенській Почаївській лаврі - «форпосту православ'я» та російського націоналізму на кордоні з католицьким світом (уособленням котрого були для Російської імперії поляки й австрійці). У 1906 р. було організовано Почаївський відділ СРН, який очолив архімандрит Віталій (Максименко), настоятель лаврия. Але головним натхненником чорносотенних сил, що мали опанувати українське Правобережжя, став архієпископ волинський і житомирський Антоній (Храповицький). У молоді роки він був офіцером, прийняв чернецтво, спілкувався з Ф.Достоєвським, послужив прототипом Альоші Карамазова ${ }^{\text {Io }}$ Значно пізніше П.Скоропадський, будучи гетьманом Української Держави, часто зустрічався з цим священнослужителем у церковних справах. За його свідченням, «митрополит Антоній був чорносотенцем старої школи, і нічого іншого, як посадити у в'язницю, розстрілювати, звернутися по сприяння

\footnotetext{
7 Омельянчук И. Черносотенное движение на территории Украины (1904-1914 гг.). - К., 2000. - С.139-143.

8 Государственная дума: Четвёртый созыв: Сессия 1. - Стб.672-673.

9 Центральний державний історичний архів України, м. Київ (далі - ЦДІАК України). - Ф.302. - Оп.1. Спр.1664. - Арк.214; Ф.442. - Оп.860. - Спр.22. - Арк.4.

${ }^{10}$ Степанов С. Чёрная сотня // Родина. - 1992. - №2. - С.20.
} 
до поліції у смислі впливу на маси для утвердження православ’я [...] не вміє» вся верхівка вищого духівництва в Україні була російського походження, «чорносотенна в повному смислі цього слова» ${ }^{12}$.

На чолі сільських відділів і підвідділів СРН часто стояли священики. У Почаївському відділі налічувалося II55 сільських підвідділів ${ }^{13}$.На Волині представники духівництва очолили близько зоо підвідділів Союзу російського народу ${ }^{14}$. Загальна чисельність Почаївського відділу становила IO4 289 осіб ${ }^{15}$. За свідченням поліцейський справників, членами СРН були місцеві православні парафіяни, переважно неграмотні. Священики у своїх проповідях прищеплювали їм російсько-патріотичні почуття, переконували в необхідності зміцнювати «російські начала» ${ }^{16}$. У ході виборчої кампанії православне духівництво переконувало селян не голосувати за поляків та євреїв, котрих характеризували як «визискувачів» місцевого населення, закликами протистояти польським поміщикам, єврейським орендарям.

Для поширення чорносотенних ідей голова Почаївського відділу архімандрит Віталій використовував лаврську друкарню. Тут видавалися поширювані серед парафіян газети «Почаевские известия», «Почаевский листок», чимало брошур, прокламацій чорносотенного змісту. Представники єврейства скаржилися на антисемітські висловлювання «Почаевского листка» до міністерства внутрішніх справ, але без усяких наслідків для цього видання. Водночас керівні органи православної церкви доклали зусиль до нейтралізації діяльності тих священиків, які брали участь в українському культурницькому русі, зокрема у «Просвіті». Інший приклад - діяльність подільського єпископа Парфенія, який очолював комісію щодо українського перекладу Нового Заповіту. Він також став ініціатором обмеженого запровадження української мови в місцевій семінарії й церковноприходських школах, дозволеного указами Св. Синоду. Проте в 1908 р. через таке «українофільство» був переведений на єпископську кафедру в Тулу ${ }^{17}$.

У Житомирі при відділі СРН було засноване Анастасіївське братство, головою якого став той самий архієпископ житомирський і волинський Антоній ${ }^{18}$. У Чернігові на чолі відділу союзу був протоієрей Васютинський ${ }^{19}$. На Катеринославщині осередки організації створювалися за ініціативи й підтримки губернської адміністрації, жандармських і судових органів ${ }^{20}$.

У Харкові діяла філія Російського зібрання, заснована за ініціативою «нащадка чугуївських козаків» професора А.Вязіхіна. Він був гласним міської думи, подавав себе шанувальником творів Г.Квітки-Основ’яненка, І.Котляревського, Т.Шевченка та українських мандрівних лірників, але вкрай вороже ставився до деяких ініціатив харківських думців. Для прикладу, 2І лютого I9I4 р. на пропозицію гласного думи М.Міхновського було ухвалено провести літературно-музикальний вечір, присвячений творчості Т.Шевченка, і заснувати при вищому училищі го стипендій його імені.

\footnotetext{
${ }^{11}$ Скоропадський П. Спогади: Кінець 1917 - грудень 1918. - К.; Філадельфія, 1995. - С.199-200.

${ }_{12}$ Там само. - С.199.

${ }^{13}$ Степанов С. Чёрная сотня в России (1905-1914). - Москва, 1992. - С.243.

${ }^{14}$ Степанов C. Численность и состав черносотенных союзов и организаций // Политические партии в России в период революции 1906-1907 гг.: Количественный анализ. - Москва, 1987. - С.198.

${ }^{15}$ Степанов С. Чёрная сотня в России... - С.108.

${ }^{16}$ ЦДІАК України. - Ф.442. - Оп.862. - Спр.90. - Арк.13.

${ }^{17}$ Гаухман $M$. Російська православна церква в російському національному проекті на Правобережній Україні (19051924 рр.) // Вісник Луганського національного університету ім. Тараса Шевченка. - Вип.11. - Луганськ, 2012. - С.83.

${ }^{18}$ ЦДІАК України. - Ф.442. - Оп.862. - Спр.90. - Арк.11.

19 Там само. - Ф.1439. - Оп.1. - Спр.919. - Арк.1.

${ }^{20}$ Союз русского народа по материалам Чрезвычайной следственной комиссии Временного правительства 1917 г. Москва; Ленинград, 1929. - С.391.
} 
А.Вязіхін став єдиним гласним, хто голосував проти. Він мотивував свою позицію тим, що поет «у ряді своїх творів дискредитує основи християнства» ${ }^{21}$. Харків був поза смугою осілості й чисельність єврейського населення була тут незначною. Проте це не заспокоїло місцевих чорносотенців і вони чинили всілякі перешкоди проникненню в місто єврейських товарів та капіталу. У зв'язку з цим перед місцевим самоуправлінням було порушено клопотання щодо дозволу приїжджим єврейським купцям проживати у Харкові під час ярмарків. Більшістю голосів, окрім одного А.Вязіхіна - було ухвалено: полегшити приїзд на ярмарки й тимчасове перебування купців-євреїв на підставі посвідчень Харківського біржового комітету. Ці факти підкреслюють погляди цього діяча 22.

Щільність єврейського населення у Херсонській губернії становила ІІ,8\%. Українців і росіян було 75,4\%, німців - 4,6\%, представників інших народів - 8,I\% $0^{23}$. Євреї зосереджувалися значною мірою у приморських містах, найбільше в Одесі. Це й визначало політику антисемітських сил. Зокрема в Одесі діяла низка монархічних і чорносотенних партій та організацій, але провідну роль відігравав саме осередок Союзу російського народу, заснований 4 лютого 1906 р. У всеросійській ієрархії Одеський відділ посідав третє місце - після Московського й Санкт-Петербурзького ${ }^{24}$. Його очолив граф Е.Коновніцин. Ще одним чорносотенним ватажком став генерал Толмачов, 2 грудня 1907 р. за рекомендацією голови СРН призначений одеським градоначальником. Він ігнорував закони, втручався не тільки в державні, але й у громадські та приватні справи, активно переслідував євреїв.

Подібними до Толмачова були й інші одеські лідери та покровителі монархістів і чорносотенців. Що стосується решти регіонів Лівобережної й Південної України, то відсоток єврейського населення там був значно меншим, це визначало відповідну чисельність «союзників» (за винятком деяких окремих міст).

Із наведених фактів постає питання щодо впливу чорносотенної пропаганди на світогляд і дії населення. Тим більше, що жителі українських міст та сіл мали безпосередні зв’язки з Головною радою СРН у Санкт-Петербурзі. Архівні матеріали свідчать, що діяльність пересічних членів була далекою від установок керівників чорносотенних організацій. Села жили традиційним життям, відстоювали сервітутні права, що походили з далеких литовсько-польських часів. Згідно з ними вели тяжби у судах із поміщиками за право випасу худоби, збирання грибів, ягід і хмизу в лісах. Попри всілякі перешкоди з боку православного духівництва кількість переходів на Правобережжі в католицизм (а на Волині - у протестантизм) зростала. У 1905 р. було зафіксовано 58 переходів у католицтво, а в 1920 р. $-747^{25} .3$ іншого боку, активісти чорносотенного руху намагалися здобути прихильність селян обіцянками віддати їм землі польських, а часто й російських поміщиків та єврейських орендарів, знизити рівень орендної плати, скасувати на місцях адміністрацію тощо. У такій гострій постановці проблем чорносотенний рух часто трансформувався у своєрідне анархо-бунтарство з елементами різних соціальних течій, що набули поширення на початку XX ст. Дедалі частіше траплялися випадки, коли чорносотенство проявлялося у вигляді безладів, брутального хуліганства, що призводило до незадоволення населення.

\footnotetext{
${ }^{21}$ Приложения к известиям Харьковской городской думы: Статистические сведения по г. Харькову. - №1: Январь: Журнал очередного собрания Харьковской городской думы: Заседание 21 февраля 1914 г. - Х., 1914. - С.24, 27.

22 Известия Харьковской городской думы. - №4. - Х., 1914. - С.17, 19.

${ }^{23}$ ЦДІАК України. - Ф.442. - Оп.644. - Спр.350. - Арк.27.

${ }^{24}$ Почаевские известия. - 1909. - 23 марта.

${ }_{25}$ Гаухман $M$. Російська православна церква в російському національному проекті... - С.85.
} 
Джерела свідчать про випадки відкриття в Україні зусиллями керівників СРН і церковних ієрархів нових відділів, які, своєю чергою, засновували підвідділи в містечках та селах. Часто це відбувалося під безпосереднім патронажем Головної ради Союзу російського народу. У Подільській губернії, наприклад, упродовж 1906-1913 рр. постали десятки відділів, у тому числі в Балтському повіті - 4, Брацлавському - 3, Вінницькому - 5, Гайсинському - 5, Летичівському - 7, Літинському - I5, Могилівському - 2, Ольгопільському - 26, Проскурівському - 9, Ушицькому - 5, Ямпільському - $\mathrm{I}^{26}$.

Конкретні дані про відкриття нових підвідділів у селах Правобережжя та про їх діяльність знаходимо в рапортах поліцейських чинів на ім'я губернаторів, а останніх - до МВС. Структури жандармерії й поліції вели спостереження за монархічними та чорносотенними організаціями, доповідаючи про їх активність державним органам. Документи, що відклалися, зокрема, у Державному архіві Київської обл. (ф.2), проливають світло на особливості селянського світогляду, причини вступу жителів у чорносотенні організації, ставлення селян до великих землевласників, єврейського населення, загалом до влади.

Аналіз рапортів і повідомлень поліцейських, жандармських чинів свідчить, що у середовищі чорносотенців були й відверто злочинні елементи - злодії, п’яниці, хулігани, причому з різних суспільних прошарків. Між активістами СРН та представниками місцевої влади періодично траплялися конфлікти. Яскраві факти з цього приводу навів у рапорті губернаторові від 7 лютого г9І3 р. мировий посередник 2-ї ділянки Липовецького повіту, котрий охарактеризував чорносотенство як «селянських рух, що його помилково називають Союзом російського народу».

Отже розуміння сутності чорносотенного руху з боку представників влади й місцевого, переважно селянського, населення часто було діаметрально протилежним. Більше того, службовці поліції та жандармерії уважно стежили за діяльністю місцевих структур СРН, щоб у разі необхідності вжити заходів.

Попри те, що до чорносотенних організацій приймали, як правило, етнічних росіян, у них були й представники інших націй і народностей, котрі ставали на службу імперській ідеї. Таких чимало налічувалося серед поляків, євреїв, українців (зокрема згадані вище яскраві представники Д.Піхно, А.Савенко).

Своєрідною була діяльність чорносотенців напередодні та в роки Першої світової війни. Вона дещо видозмінювалася під впливом загострення внутрішньополітичного життя та подій на фронті. Проте загалом визначалася ворожим ставленням до національних рухів усередині Росії, до зростання самосвідомості неросіян. Праві й ультраправі виправдовували воєнні катастрофи нібито «підривною діяльністю» «інородців». У Державній думі всі негаразди внутрішнього життя імперії чорносотенці пояснювали «підступами юдеїв», поляків, німців, українців («мазепинців»)27. Водночас усіляко роздмухували шпигуноманію, нагнітали антисемітські та ксенофобські настрої. Зовнішня політика Росії в роки війни залишалася імперіалістичною, загарбницькою. Вона знаходила підтримку з боку тогочасного політикуму - конституційних демократів, октябристів, прогресистів, і ще більше від представників правих та ультраправих у Держдумі. У внутрішній політиці верховна влада дедалі зближувалася з останніми ${ }^{28}$.

\footnotetext{
${ }^{26}$ Кам’янець-Подільський міський державний архів. - Ф.228. - Оп.1. - Спр.8277. - Арк.2-4 зв.

${ }_{27}$ Стенографический отчёт Государственной думы: Четвёртый созыв: Сессия IV. - Стб.49-52; Сессия 1. - Ч.1. Стб.2470.

${ }_{28}$ Див.: Хрущев А. Андрей Иванович Шингарёв, его жизнь и деятельность. - Москва, 1918. - С.69.
} 
Аналіз феномену чорносотенства донині зберігає свою «виняткову злободенність ${ }^{29}$. Дослідники цієї проблеми аналізували різні ії аспекти, а дехто навіть удавався до порівняння російського чорносотенства з італійським фашизмом або німецьким націонал-соціалізмом. Ми дозволимо собі висловити інше розуміння цього явища, що народилося у суспільстві країни, яка запізнилася на шляху історичного розвитку.

На початку XX ст. в Російській імперії відбувався розвиток капіталізму, проте на політичній сцені домінували представники дворянства, пов'язаного з кріпосницькими пережитками у вигляді великого землеволодіння. На чолі владної піраміди, що склалася в попередні століття, перебував монарх, самодержець усеросійський, якому підпорядковувався державний апарат з каральними та силовими відомствами. Саме зусиллями останнього було придушено виступи 1905-1907 pр., які могли знищити стару систему влади й оновити політико-правовий та соціально-економічний устрій імперії. Поразка революції зупинила цю тенденцію, у тому числі процес заміни старих еліт, котрі гальмували розвиток продуктивних сил. Загалом це означало збереження при владі попередньої консервативної бюрократії. Ледве не єдиним наслідком революції стала поступка самодержавства у вигляді Маніфесту 17 жовтня, коли суспільство отримало певні політичні свободи, основні закони й консервативну Державну думу з обмеженими на користь монарха законодавчими правами. Однак, оговтавшись, реакційні сили перейшли в наступ і прагнули звести нанівець поступку, зроблену імператором Миколою II у вигляді згаданого маніфесту. За таких обставин у верховному владному ешелоні, перш за все у IV Думі, ішло протиборство між прибічниками необмеженого самодержавства і прихильниками створення уряду, відповідального перед представницькими установами. Чорносотенні партії, що виникли у ході революції 1905-1907 pр., зарекомендували себе запеклими оборонцями необмеженого самовладдя. Із метою розширення власної соціальної бази вони видавали себе «захисниками» російського народу від «інородців», удавалися до антисемітизму і ксенофобії задля підтримки царату й боротьби з національно-визвольними рухами. Про це свідчать, зокрема, гострі дискусії з національного питання. Так, шукаючи підтримки виборців, правий політик і публіцист М.Марков 2-й висловлювався з цього приводу гранично відверто: «Державній думі давно вже настав час без усякого лицемірства визнати просту істину, яку ми, праві, висловлюємо ось уже шостий рік. Це та істина, що в російській державі російський народ має бути на першому місці» ${ }^{30}$. Слова одного 3 лідерів чорносотенців були відображенням їхніх прагнень досягти повного домінування російської народності на «національних окраїнах» імперії шляхом асиміляції та міграційної політики.

Головним стрижнем чорносотенного руху було, безумовно, дворянство, яке доклало зусиль до збереження необмеженого самодержавства, своїх привілеїв і землеволодіння. Перебуваючи на ключових посадах у державному апараті, армії, поліції дворяни розглядали єврейство як конкурентну силу у суспільно-політичному житті й усіляко обмежували їхні можливості у цій сфері. Найбільш яскраво це проявлялося в освіті. Окремі групи промислової буржуазії та майже все російське купецтво виражали прихильність до чорносотенного руху. Це пояснюється переважно чинниками економічного характеру, прагненням убезпечити себе від конкуренції з боку єврейської буржуазії, яка досягла великих успіхів найперше в галузях переробки

\footnotetext{
${ }_{29}$ Шевченко А. Черносотенный сценарий национал-патриотизма и современная Россия // Омельянчук И. Черносотенное движение на территории Украины (1904-1914 гг.). - С.4.

${ }^{30}$ Государственная дума: Четвёртый созыв: Сессия 1. - Стб.2296.
} 
сільськогосподарської продукції. Дрібна буржуазія і працівники різноманітних майстерень, кустарних промислів теж були незадоволені суперництвом із боку єврейських торговців. Саме вони ставали учасниками погромів. Частина російської інтелігенції, особливо на «національних окраїнах» імперії, також виявляла прихильність до чорносотенного руху.

Найбільш суперечливим і неоднозначним було ставлення до чорносотенців духівництва й селянства, зокрема на теренах українського Правобережжя. На причетність священнослужителів до цього руху впливав такий чинник, як суперництво з іншими релігійними конфесіями - католицизмом, протестантизмом, юдаїзмом. Однак погляди учасників тих подій, документальні матеріали й архівні джерела неспростовно доводять, що активну роль у поширенні чорносотенства відігравали тут ієрархи православної церкви саме російського походження. Рядове духівництво, за свідченням місцевих поліцейських чиновників, як правило, не прагнуло брати участь у чорносотенному русі ${ }^{31}$. Відносини селян та євреїв у місцевостях, де активісти Союзу російського народу вели антисемітську пропаганду та організовувалися споживчі товариства, були напруженими внаслідок конкуренції в торгівлі. Проте селяни зневажливо ставилися до членів СРН, що пояснюється бешкетами, хуліганством останніх. 3 іншого боку, неосвічена селянська маса перебувала в полоні ілюзорних сподівань на підтримку центральної влади й особисто «царя-батечка» в питаннях оплати праці у приватновласницьких економіях, щодо передачі поміщицьких земель. Тим більше, що такі уявлення поширювали самі «союзники». Тож чорносотенний рух на Правобережжі виливався у своєрідну війну між селянами і власниками земельних латифундій. Останні вже були готові об'єднатися й задля порятунку оголосити локаут. 3 огляду на ці та деякі інші факти дещо наївними видаються оцінки окремих дослідників, котрі оголосили українське Правобережжя «бастіоном» чорносотенства в Російській імперії. Відділи та підвідділи СРН у цьому perioнi справді мали вражаючу загальну чисельність. Але період їх функціонування часто був нетривалим через розчарування, байдуже ставлення до них селян. Зусиллями активу, стимульованого зі Санкт-Петербурга, вони організовувалися, а через деякий час розсипалися та зникали, про що свідчать рапорти поліцейських справників. Це пояснюється ще й тим, що українське селянство було далеким від російської державно-національної свідомості. Загалом чорносотенці, вірнопіддані «государя-імператора», намагалися відстоювати його історичні прерогативи, а тому протиставляли свою ідеологію ліберальним і соціалістичним ідеям та активно боролися з національно-визвольним рухом. Вони були продуктом політико-правових і соціально-економічних умов життя російського суспільства в період глибокої й масштабної політико-економічної кризи.

\section{REFERENCES}

1. Haukhman, M. (2012). Rosiiska pravoslavna tserkva v rosiiskomu natsionalnomu proekti na Pravoberezhnii Ukrain (1905-1924 rr.). Visnyk Lubanskobo natsionalnobo universytetu im. Tarasa Shevchenka, 11, 78-89. [in Ukrainian].

2. Omelyanchuk, I. (2000). Chernosotennoe dvyzhenye na terrytoryy Ukrayny (1904-1914 gg.). Kiev. [in Russian].

3. Stepanov, S. (1987). Chislennost i sostav chernosotennykh soyuzov i organizatsyy. Politicheskye partii v Rossii v period revolyutsiy 1906-1907 gg.: Kolichestvennyy analiz. Moskva. [in Russian].

4. Stepanov, S. (1992). Chernaya sotnya v Rossyy (1905-1907). Moskva. [in Russian].

\footnotetext{
${ }^{31}$ Державний архів Київської обл. - Ф.2. - Оп.229. - Спр.58. - Арк.35-35 зв.
} 


\title{
Oleksandr REIENT
}

Doctor of Historical Sciences (Dr. Hab. in History), Professor,

Corresponding Member of NAS of Ukraine,

Deputy Director of Institute of History of Ukraine NAS of Ukraine

(Kyiv, Ukraine), Reent.O.P@nas.gov.ua

ORCID: https://orcid.org/oooo-oooI-5I4I-7445

\section{Oleksandr SERDIUK}

Candidate of Historical Sciences (Ph. D. in History)

(Kyiv, Ukraine), historydepartmentı9@gmail.com

ORCID: https://orcid.org/oooo-ooo2-2I09-7900

\section{Black Hundreds: Ukrainian Aspect (End of the Nineteenth Century - 1917)}

\begin{abstract}
The purpose of the article is to reconstruct and analyze the main stages and features of the Black Hundreds movement in Ukraine in the end of the $19^{\text {th }}$ century and during the World War I. The research methodology is based on the principles of historicism, scientificity, objectivity. Comparative-historical, analytical-septic methods, methods of scientific criticism of sources, interdisciplinary approach are used. Scientific novelty. On the basis of the processed sources, a significant part of which is first introduced into scientific circulation, the specifics of the Black Hundreds movement in Ukraine at the end of the $19^{\text {th }}$ century are characterized and in the first decades of the $20^{\text {th }}$ century. Results of the research. The issue of the Black Hundreds movement in the Russian Empire in the early $20^{\text {th }}$ century, despite all its complexity and contradictions, has been quite successfully studied by Russian, Ukrainian, Jewish and other historians and publicists for over a century. The history of the origin and formation of the Black Hundreds parties and organizations, their number and social composition in Ukraine and in the empire in general has been significantly studied. Various currents in the Black Hundreds were analyzed - from moderate to extremist, the course of the Jewish pogroms and the causes of anti-Semitism. Researchers have paid less attention to the ties of the Black Hundreds and their leaders with Russian monarchism, the broad peasantry, and the hierarchs of the Russian Orthodox Church. The Duma tactics of the Black Hundreds, their attitude to the tsarist manifesto of October 17, 1905, and the problems of constitutionalism after its promulgation were even less well covered. The activity of the Black Hundreds during the World War I remains a serious gap in the national historiography.
\end{abstract}

Keywords: Black Hundreds movement, Russian Empire, Ukraine, Jewish pogroms, government national policy. 